\title{
COMPARISON OF IRISIN SERUM HEALTHY UNTRAINED MALES ON TREADMILL EXERCISES BY INCREASING GRADUALLY SPEED VS INCLINATION
}

\author{
Uda'a $B^{1}$, Tinduh $D^{1}$, Masduchi $H R^{1}$, Laswati $H^{1}$, Wibisono $S^{2}$, Soenatalina ${ }^{3}$, Theodora $S^{1}$ \\ ${ }^{1}$ Department of Physical Medicine and Rehabilitation, ${ }^{2}$ Consultants of Endocrinology, Metabolic and Diabetes, \\ Department of Internal Medicine, Faculty of Medicine, Universitas Airlangga, Dr. Soetomo Hospital, Surabaya, \\ ${ }^{3}$ Faculty of Public Health, Universitas Airlangga, Surabaya, Indonesia
}

\section{ABSTRACT}

\begin{abstract}
Aerobic exercise can improve cardiorespiratory fitness in young people. Irises released into the bloodstream function to execute regulation of energy metabolism, triggering browning white adipose, which is useful in mitochondrial biogenesis. The American College of Sport Medicine (ACSM) recommends moderate intensity cardiorespiratory fitness training with a frequency of 3-5 times a week, duration of 20-60 minutes, using a treadmill. Study subjects $(n=20)$ were divided randomly into 2 groups, namely the moderate intensity Treadmill training group with gradual speed improvement and gradual inclination increase. Serum slices are measured on the first and last day of exercise. There was an increasing of irisin serum in the moderate intensity Treadmill training group by increasing gradually speed after 2 weeks of exercise, both 30 minutes preexercise $(p=0.02)$ and 1 hour post exercise $(p=0.01)$. Medium intensity Treadmill training with 2 weeks gradual speed increase with frequency 3 times a week can increase serum slice in men, healthy untrained young men.
\end{abstract}

Keywords: Moderate intensity treadmill exercise; aerobic exercise; irisin serum; speed increase gradual; gradual inclination increase

\section{ABSTRAK}

Latihan aerobik dapat meningkatkan kebugaran kardiorespirasi pada orang muda. Iris dilepaskan ke dalam fungsi aliran darah untuk melaksanakan regulasi metabolisme energi, memicu adiposa putih kecoklatan, yang berguna dalam biogenesis mitokondria. American College of Sport Medicine (ACSM) merekomendasikan pelatihan kebugaran kardiorespirasi intensitas sedang dengan frekuensi 3-5 kali seminggu, durasi 20-60 menit, menggunakan treadmill. Subjek penelitian $(n=20)$ dibagi secara acak menjadi 2 kelompok, yaitu kelompok pelatihan Treadmill intensitas sedang dengan peningkatan kecepatan bertahap dan peningkatan kecenderungan bertahap. Irisan serum diukur pada hari pertama dan terakhir latihan. Ada peningkatan serum irisin dalam kelompok intensitas sedang pelatihan Treadmill dengan meningkatkan kecepatan secara bertahap setelah 2 minggu latihan, baik 30 menit sebelum latihan $(p=0,02)$ dan 1 jam setelah latihan $(p=0,01)$. Intensitas sedang Pelatihan treadmill dengan 2 minggu peningkatan kecepatan bertahap dengan frekuensi 3 kali seminggu dapat meningkatkan slice serum pada pria, pria muda yang sehat dan tidak terlatih.

Kata kunci: Latihan treadmill intensitas sedang; olahraga aerobik, serum irisin; peningkatan kecepatan bertahap; peningkatan kecenderungan bertahap

Correspondence: Budiyanto Uda'a, Jl. KH. Agus Salim no. 44 Luwuk, Sulawesi Tengah, Indonesia.

Phone: 081342028080. E-mail: budi_andina@yahoo.com

pISSN:2355-8393 • eISSN: 2599-056x • doi: 10.20473/fmi.v56i1.18451

- Fol Med Indones. 2020;56:49-55 • Received 6 Nov $2018 \bullet$ Accepted 16 May 2019

- Open access under CC-BY-NC-SA license • Available at https://e-journal.unair.ac.id/FMI/

\section{INTRODUCTION}

Aerobic exercise can improve cardiorespiratory fitness in young people. The irisin is released into the bloodstream, it functions to execute the regulation of energy metabolism, triggering white adipose browning, which is useful in mitochondrial biogenesis (Inyang \& Stella 2015, Plowman \& Smith 2014, Pescatello et al 2014). The most common aerobic exercise used for cardiorespiratory fitness training is moderate intensity. Aerobic exercise can also cause changes in mitochondrial density, where mitochondria are involved in the use of oxygen for produce Adenosine TriPhosphate (ATP) as a form of energy, resulting in increased muscle endurance (Abrantes et al 2012). The American College of Sport Medicine (ACSM) recommends moderate intensity cardiorespiratory fitness training with a frequency of 3-5 times a week, 
duration of 20-60 minutes, using a treadmill Plowman \& Smith 2014, Pescatello et al 2014).

Treadmilll is one exercise tool that is used to train cardiorespiratory fitness and training tests to determine individual VO2max values. The advantage of treadmill is one of the simple and applicable aerobic exercise modalities in accordance with the daily physical activities carried out, namely walking (Kuys et al 2008).

The treadmill training component consists of speed and inclination. Treadmill training to improve cardiorespiratory fitness can be done by increasing the speed and inclination to achieve the target heart rate according to the desired exercise intensity (Ferley et al 2014, Norheim et al 2013). Irisin is a polypeptide hormone derived from proteolitytic cleavage protein fibronectin-type III domain containing 5 (FNDC5). If irisin releases into the circulation during exercise or due to cold exposure, irisin will stimulate browning of white adypose tissue (WAT), and uncoupling protein 1 (UCP1) elevated with increased of energy expenditure through the addition of thermogenesis-mediated UCP1. Park's study showed that irisin increase twice immediately after acute exercise and returned to baseline after 2 hours of rest. There was no significant increase in irisin after 12 weeks of endurance training in healthy people (Norheim et al 2013, Zhao et al 2017, Zhang et al 2017). There are few studies comparing gradual increase in speed and incremental inclination in treadmill exercise to improvement of irisin serum. The aim of this study was to compare serum irisin levels in medium intensity treadmill exercises with gradual speed increase and with gradual inclination increases in healthy untrained young male.

\section{MATERIALS AND METHODS}

This study was conducted for 2 weeks with the number of participants 20 people who met the inclusion criteria and did not include exclusion criteria. Most of the subjects are employees Medical Rehabilitation Unit of Dr. Soetomo hospital in Surabaya. Inclusion criteria were healthy men, aged 26-35 years, Body Mass Index (BMI) $18.5-22.9 \mathrm{~kg} / \mathrm{m} 2$, systolic blood pressure 110 $130 \mathrm{mmHg} /$ diastole $70-80 \mathrm{mmHg}$, willing to participate in this study by signed informed consent and medical action approval sheet. Exclusion criteria is undergoing a routine aerobic exercise program 2 times a week; suffering from ischemic heart disease, restrictive or obstructive airway disease, neuromusculoskeletal disease in the lower limbs; have motion of both ankle joints for plantar flexion over 45 degrees and dorsiflexion over 30 degrees. The criteria for drop out of the test were that the research subjects were not willing to continue the research for any reason, the subjects could not complete the training in accordance with the established research protocol, if there was a complaint of chest pain or tightness during or after exercise, if there was a complaint of calf pain during or after exercise, the subjects were unable to complete the training according to the research protocol that had been determined, or participant were unable to complete the treadmill training in accordance with the training protocol used in this study for 2 consecutive training sessions of the total number of training sessions for 2 weeks of training.

The technique of taking participants with consecutive sampling technique. The study was conducted from April to May 2018, located in the gait laboratory Medical Rehabilitation Unit of Dr. Soetomo hospital in Surabaya, using EN-Mill® Treadmill, and this research has received Ethical eligibility from the Ethics Committee of Dr. RSUD. Soetomo Surabaya with number 0304/KEPK/V/2018.

Participants were randomized using sweepstakes into two groups, namely the group that received moderate intensity treadmill training with gradual speed improvement and the group that received moderate intensity treadmill training with gradual inclination improvement. The medium intensity treadmill training group with gradual speed improvement received moderate intensity treadmill training $(70 \%$ maximum heart rate) with gradual increase in speed during exercise and permanent inclination. Whereas the group that received moderate intensity treadmill training with increased inclination gradually received moderate intensity treadmill exercise ( $70 \%$ maximum heart rate) with a gradual increase in inclination during exercise and steady pace. Frequency of exercise 3 times a week, and carried out for 2 weeks. Measurement of serum irisin levels was carried out 30 minutes pre and 60 minutes post exercise the first day, and 30 minutes pre and 60 minutes after the sixth day exercise in a 2 week exercise program Data were analyzed computerized with SPSS using several tests, namely: Kolmogorov one-sample test Smirnov to determine data homogenity in each group A and B, paired t-test to compare serum irisin levels before and after exercise program for 4 weeks in each group A and B, t-2 test free sample (independent t-test) to compare serum irisine levels before and after a 2-week exercise program between groups $\mathrm{A}$ and $\mathrm{B}$.

\section{RESULTS}

Prior to statistical analysis, normality and homogenity tests were carried out on the characteristics of research 
subjects using the Kolmogorov one-sample test Smirnov test, the results of which could be seen in Table 1 .

The Kolmogorov-Smirnov test results showed that the age, heart rate and Body Mass Index (BMI) data in both groups were normally distributed so that parametric statistical tests were used. The mean age of the study subjects in the inclination group was $31.1 \pm 2.92$ years, while the speed group was $32.3 \pm 2.31$ years. Based on the Independent $\mathrm{T}$ test statistical test, no significant differences were found for the age characteristics of the study subjects between the two groups with the price of $\mathrm{p}=0.322(\mathrm{p}<0.05)$. The mean heart rate of the study subjects in the inclination group was $83.9 \pm 4.14$ times/minute, while the speed group was $84.5 \pm 2.91$ times/minute. Based on the Independent $T$ test statistical test, there were no significant differences in the heart rate characteristics of the study subjects between the two groups with the price of $p=0.713(\mathrm{p}<0.05)$.

The mean BMI of the study subjects in the inclination group was $21.9 \pm 1.43 \mathrm{~kg} / \mathrm{m} 2$, while the speed group was $22.6 \pm 1.54 \mathrm{~kg} / \mathrm{m} 2$. Based on the Independent T test statistical test, there were no significant differences in the BMI characteristics of the study subjects between the two groups $\mathrm{p}=0.465$ ( $\mathrm{p}<0.05)$. Data on serum slices of pre and post exercise both first week and second week were also normally distributed in both groups.

Kolmogorov-Smirnov test results showed that the serum irisin level data was normally distributed so that parametric statistical tests were used. The mean level of serum irisin of the study subjects in the pre-exercise inclination group was $5.63 \pm 0.73 \mu \mathrm{g} / \mathrm{ml}$, whereas after the first week of exercise was $5.58 \pm 1.56 \mu \mathrm{g} / \mathrm{ml}$. Based on the Independent $\mathrm{T}$ test statistical test, there were no significant differences in serum irisin levels between pre and post week I exercise for subjects in the inclination group at a price of $\mathrm{p}=0.890(\mathrm{p}<0.05)$. The mean serum irisin level of the study subjects in the pre-exercise inclination group was $5.06 \pm 1.40 \mu \mathrm{g} / \mathrm{ml}$, while the posttreatment was $5.38 \pm 0.98 \mu \mathrm{g} / \mathrm{ml}$. Based on the Independent $\mathrm{T}$ test statistical test, there were no significant differences in serum irisin levels between pre and post treatment week II for subjects in the inclination group with a price of $\mathrm{p}=0.305(\mathrm{p}<0.05)$.

Table 1. Participants characteristics

\begin{tabular}{|c|c|c|c|}
\hline Characteristics & $\begin{array}{c}\text { Inclination } \\
(\mathrm{n}=10)\end{array}$ & $\begin{array}{c}\text { Speed } \\
(\mathrm{n}=10)\end{array}$ & $\mathrm{p}$ \\
\hline Age (year) & $31.1 \pm 2.92$ & $32.3 \pm 2.31$ & 0.322 \\
\hline Heart $\operatorname{rate}(\mathrm{x} / \mathrm{mnt})$ & $83.9 \pm 4.14$ & $84.5 \pm 2.91$ & 0.713 \\
\hline BMI (Body Mass Index) $\left(\mathrm{kg} / \mathrm{m}^{2}\right)$ & $21.9 \pm 1.43$ & $22.6 \pm 1.54$ & 0.465 \\
\hline $\begin{array}{l}\text { Irisin serum baseline level pre exercise day } 1 \\
(\mathrm{ng} / \mathrm{ml})\end{array}$ & $5.63 \pm 0.73$ & $4.79 \pm 1.53$ & 0.259 \\
\hline $\begin{array}{l}\text { Irisin serum baseline level post exercise day } \\
1(\mathrm{ng} / \mathrm{ml})\end{array}$ & $5.58 \pm 1.56$ & $5.05 \pm 1.45$ & 0.590 \\
\hline $\begin{array}{l}\text { Irisin serum baseline level pre exercise day } 6 \\
(\mathrm{ng} / \mathrm{ml})\end{array}$ & $5.06 \pm 1.40$ & $6.49 \pm 0.90$ & 0.259 \\
\hline $\begin{array}{l}\text { Irisin serum baseline level post exercise day } \\
(\mathrm{ng} / \mathrm{ml})\end{array}$ & $5.38 \pm 0.98$ & $6.40 \pm 1.11$ & 0.590 \\
\hline
\end{tabular}

Table 2. Comparison irisin serum (ng/ml) pre and post week I and II (in group)

\begin{tabular}{lcccccc}
\hline \multicolumn{1}{c}{ Groups } & Pre Week I & Post week I & P & Post week II & Post week II & p \\
\hline Inclination & $5.63 \pm 0.73$ & $5.58 \pm 1.56$ & 0.890 & $5.06 \pm 1.40$ & $5.38 \pm 0.98$ & 0.305 \\
Speed & $4.79 \pm 1.53$ & $5.05 \pm 1.45$ & 0.530 & $6.49 \pm 0.90$ & $6.40 \pm 1.11$ & 0.686 \\
\hline Note: $p$ value is significant if $<0.05$ & & & &
\end{tabular}

Table 3. Comparison irisin serum (ng/ml) pre-pre and post-post baseline and week II (in group)

\begin{tabular}{lcccccc}
\hline \multicolumn{1}{c}{ Groups } & Pre week I & Post week I & P & Pre week II & Post week II & p \\
\hline Inclination & $5.63 \pm 0.73$ & $5.06 \pm 1.40$ & 0.259 & $5.58 \pm 1.5 p-=6$ & $5.38 \pm 0.98$ & 0.590 \\
Speed & $4.79 \pm 1.53$ & $6.49 \pm 0.90$ & $0.002^{*}$ & $5.05 \pm 1.45$ & $6.40 \pm 1.11$ & $0.010^{*}$ \\
\hline
\end{tabular}

Note: $p$ value is significant if $<0.05$, *significant 
Table 4. Comparison irisin serum (ng/ml) pre-post week I and week II (in group)

\begin{tabular}{lccc}
\hline \multicolumn{1}{c}{ Groups } & Pre-Post week I & Pre-Post week II & $\mathrm{p}$ \\
\hline Inclination & $0.05 \pm 1.11$ & $-0.32 \pm 0.93$ & 0.505 \\
Speed & $-0.26 \pm 1.25$ & $0.09 \pm 0.68$ & 0.454 \\
\hline
\end{tabular}

Note: $\mathrm{p}$ value is significant if $<0.05$

Tabel 5. Comparison increasing irisin serum ( $\mathrm{ng} / \mathrm{ml})$ between inclination and speed groups

\begin{tabular}{lccc}
\hline \multicolumn{1}{c}{ Variable } & Inclination & Speed & $\mathrm{p}$ \\
\hline Pre day 1-pre day 6 & $0.05 \pm 1.11$ & $-0.26 \pm 1.25$ & 0.567 \\
Post day 1-post day 6 & $-0.32 \pm 0.93$ & $0.09 \pm 0.68$ & 0.275 \\
\hline
\end{tabular}

Note: $p$ value is meaningful if $<0.05$

The results of the comparison between the pre-exercise week I and the second week pre-training in the inclination group did not show a significant difference of $p=0.259(p<0.05)$, nor did the comparison results after the first week of exercise and after the second week of exercise in the inclination group did not show results. meaningful $\mathrm{p}=0.590(\mathrm{p}<0.05)$.

Parametric statistical test results in the speed group also showed results that were not much different, where the mean serum I irisin level in the study subjects in the pre-exercise speed group was $4.79 \pm 1.53 \mu \mathrm{g} / \mathrm{ml}$, while post exercise was $5.05 \pm 1,45 \mu \mathrm{g} / \mathrm{ml}$. The mean serum irisin level in the second week of the study subjects in the pre-exercise speed group was $6.49 \pm 0.90 \mu \mathrm{g} / \mathrm{ml}$, while the post-exercise was $6.40 \pm 1.11 \mu \mathrm{g} / \mathrm{ml}$.

Different results were found in the speed group, where the results of the comparison of the pre-training week I and pre-training week II in the velocity group showed significant differences $\mathrm{p}=0.002(\mathrm{p}<0.05)$. Significant differences were also found in the comparison results after the first week of training and after the second week of training at the speed group $\mathrm{p}=0.10(\mathrm{p}<0.05)$.

Comparison of irisin levels in the inclination group and speed is calculated using the Independent sample test statistical test, because the data is normally distributed. Static test results showed no significant difference in irisin increase between inclination groups and velocity groups both pre-post exercise $p=0.567(\mathrm{p}>0.05)$ and pre-post exercise II $p=0.275(\mathrm{p}>0.05)$ after get an intensity fitness exercise using a treadmill for 2 weeks, can be seen in Table 5 .

\section{DISCUSSION}

The mean age of participants in both groups was 32 and 31 (Table 1) which showed that the average participants were still in the productive age range which still allowed cardiorespiratory fitness training to reduce the risk of developing the disease.

The mean basal heart rate (Table 2) shows the heart rate of the study subjects in normal scope. During the exercise, showed improvement in basal heart rate. Improvement of heart rate in participants after receiving treadmill intensity training was in line with previous studies which stated that the mechanism of compensation for heart rate 1-4 was lower after receiving moderate intensity fitness training (Colaianni \& Grano 2010, Benedini et al 2017, Fatouros 2017).

Increased levels of pre-basal serum iris and 1 hour postexercise in the aerobic exercise group with a significant increase in gradual inclination were not significant. Gradual inclination increases involving more working muscles compared to gradual increase in speed. The muscles involved not only work to produce energy but also play a role in maintaining balance when climbing up on the treadmill. This condition allows not only irisin which is released by the muscle to the cellular, so that the serum irisin level is not significantly increased, although the data shows an increase in some subjects (Pescatello et al 2014, Perakakis et al 2017, Zhang et al 2015, Arias-Loste et al 2014). The duration required with a gradual increase in inclination to reach THR also affects the results of serum irisin levels. Slower inclination increases compared to increased speed, causing the use of type II muscle fibers to produce slower energy compared to gradual increase in speed. This situation may also affect the amount of serum irisin released to cellular, but this phenomenon still needs further research to prove it (Zhang et al 2017, Perakakis et al 2017, Arias-Loste et al 2014).

The results of this study showed that there were no significant differences in serum irisin levels in pre and post 2 weeks of cardiorespiratory fitness training using medium intensity treadmills with gradual increase in 
speed and incremental increments. A study showed that there was a significant increase in serum irisin levels at 3 minutes after moderate intensity aerobic exercise, but there was a decrease approaching basal values at 1 hour after exercise. In other studies showed that there was an insignificant increase in serum irisin levels in untrained subjects who were given aerobic exercise for 12 weeks, but in healthy subjects of old age there was an increase in serum irisin levels after 6 weeks of aerobic exercise (So et al 2014, Daskalopoulou et al 2014, Kerstholt et al 2015).

Another study showed an increase in serum irisin levels in subjects who received high intensity aerobic exercise compared to moderate intensity. The results of these studies are in accordance with the results of this study, which shows that irisin has an acute effect on exercise that is at 3 minutes after exercise. Irises are also affected by exercise intensity, high intensity in aerobic exercise will have a significant impact on serum irisin levels. The length of time the exercise does not show a positive correlation to elevated serum irisin levels, but this does not mean that aerobic exercise is not ideal for a long period of time to increase serum irisin levels because further research is needed on this subject (Norheim et al 2013, So et al 2014, Daskalopoulou et al 2014, Kerstholt et al 2015).

Increased levels of pre-exercise basal serum irisin and serum irisin levels 1 hour after exercise in the speed group according to previous studies. Other studies say that there is an increase in serum irisin in individuals who do aerobic exercise by running on a treadmill. This is possible because the release of serum irisin from the muscles of the lower limbs to the cellular triggers the formation of UCP-1 which plays a role in browning WAT (Sanchez-Delgado et al 2015, Tang et al 2016, Hoffmann et al 2014, Panati et al 2016, Jacobs 2015). Browning WAT or called brite adypose triggers mitochondrial biogenesis in WAT to produce ATP. Increased serum irisin levels indicate increased amounts of brite adypose, which reflects increased oxygenation in muscle cells. This situation correlates with an increase in cardiorespiratory fitness as a goal of aerobic exercise (Norheim et al 2013, Zhao et al 2017, Kisan et al 2012, Polen \& Joshi 2014, Gibbons et al 2002, Porszasz et al 2003).

Previous studies have shown that increasing levels of serum irisin in young pradiabetic patients has a positive correlation with inhibition of insulin resistance (Gibbons et al 2002, Badawy \& Muaidi 2017, Froelicher et al 1975, Harun et al 1995, Pratanu 2008). Increased levels of serum irisin obtained one of them with aerobic exercise (Norheim et al 2013, SanchezDelgado et al 2015, Panati et al 2016, American Heart
Association Guidelines for Cardiopulmonary Resuscitation and Emergency Cardiovascular Care Science 2010, Tsuchiya et al 2014, WHO 2000).

The homogeneous age, level of activity, and BMI in this study have reduced the bias towards the results of serum irisin levels, but still require further scientific studies through more specific studies to assess the correlation of these factors in aerobic exercise using a treadmill with incremental increments (Zhao et al 2017, Hamlin et al 2012, Niemann 2011, Ferley et al 2014, Kim et al 2016).

\section{CONCLUSION}

Medium intensity Treadmill training with a gradual increase in speed for 2 weeks with a frequency of 3 times a week can increase serum slice in men, healthy young males not trained. Research limitation is lack of literature and research on the effect of exercise on serum irisin causes difficulties for researchers to determine the right time to see the effect of increased serum irisin. The duration of exercise and the short frequency in the study could not show the actual increase in irisin in the inclination group. Body fat composition also affects the levels of serum slices and aerobic exercise. The failure to measure the fat composition in this study also becomes one of the research limitations that can be corrected in subsequent studies.

\section{REFFERENCES}

Abrantes C, Sampaio J, Reis VM, Sousa N and Duarte JA (2012). Physiological responses to treadmill and cycle exercise. Int J Sport Med 33, 26-30

American Heart Association Guidelines for Cardiopulmonary Resuscitation and Emergency Cardiovascular Care Science (2010). Circulation Journal of the American Heart Association 122, 639934

Arias-Loste MT, Ranchal I, Romero-Gomez M, and Crespo J (2014). Irisin, a link among fatty liver disease, physical inactivity and insulin resistance. Review article in International Journal of Molecular Sciences 15, 23163-78

Badawy G, Muaidi QI (2017). Cardiorespiratory response; Validation of new modifications of Bruce protocol for exercise testing and training in elite Saudi Triathlon soccer players. Saudi Journal of Biological Sciences

Balady GJ (2010). Clinician's guide to cardiopulmonary exercise testing in adults: a scientific statement from 
the American Heart Association. Circulation 122, 191225

Benedini S, Dozio E, Invernizzi PL, Vianello E, Banfi G, Teruzzi I, Luzi L, Romanelli MMC (2017). Irisin: a potential link between physical exercise and metabolism-an observational study in differently trained subjects, from elite athletes to sedentary subjects. Research article in Hindawi Journal of diabetes research 2017, 1-7

Colaianni G, Grano M (2010). Role of Irisin on the bone-muscle functional unit. Review article in BoneKey 765, 1-4

Daskalopoulou SS, Cooke AB, Gomez YH, Mutter AF, Filippaios A, Mesfum ET, Mantzoros CS (2014). Plasma irisin levels progressively increase in response to increasing exercise workloads in young, healthy, active subjects. Clinical study in European journal of endocrinology Journal 171, 343-52

Fatouros IG (2017). Is irisin the new player in exerciseinduced adaptations or not? A 2017 update. Review article in Clin Chem Lab, 1-22

Ferley DD, Osborn RW, Vukovich MD (2014). The effects of incline and level grade high intesity interval treadmill training on running economy and muscle power in well-trained distance runners.. Journal of Strength and conditioning research 28, 1298-1309

Ferley DD, Osborn RW, Vukovich MD (2014). The effects of incline and level grade high intesity interval treadmill training on running economy and muscle power in well-trained distance runners. Journal of Strength and conditioning research 28, 1298-1309

Froelicher VF, Thompson AJ, Davis G, Stewart AJ, Triebwasser JH (1975). Pradiction of maximal oxygen consumption : comparison of the Bruce and Balke treadmill protocols. Chest 68, 331-336

Gibbons RJ, Balady GJ, Bricker JT (2002). ACC/AHA 2002 guideline update for exercise testing: a report of the American College of Cardiology/American Heart Association task force on practice guidelines. Circulation 106, 1883-1892

Hamlin MJ, Draper N, Blackwell G, Shearman JP and Kimber NE (2012). Determination of maximal oxygen uptake using the bruce or a novel athlete-led protocol in a mixed population. Journal of Human Kinetics 31, 97-104

Harun SR, Putra ST, Wiharta AS, Chair IC (1995). Uji Klinis. In Dasar-dasar Metodologi Penelitian Klinis. Jakarta, Binarupa Aksara, p 115-17

Hoffmann T, Elbelt U, Stengel A (2014). Irisin as a muscle-derived hormone stimulating thermogenesis. A critical update in peptides journal, 89-100

Inyang MP, Stella O (2015). Sedentary lifestyle: health Implications. Journal of Nursing and Health Science 4, 20-25
Jacobs C (2015). Sports and fitness industry surpasses $\$ 84$ billion in wholesale sales. Sports and Fitness Industry Association

Kerstholt N, Ewert R, Nauck M, Spielhagen T, Bollmann T, Stubbe B, Felix SB, Wallaschofski H, Friedrich N (2015). Association of circulating irisin and cardiopulmonary exercise capacity in healthy volunteers: result of the study of health in pomerania. Research article in BMC pulmonary medicine 15, 1-9

Kim HJ, Lee HJ, So B, Son JS, Yoon D, Song W (2016). Effect of aerobic training and resistance training on circulating Irisin level and their association with change of body composition in overweight/obese adults. A pilot study in Physiological research journal 65, 271-79

Kisan R, Ravikiran S, Anita OR, Chandrakala SP (2012). Treadmill and bycycle ergometer exercise: cardiovascular response comparison. Global Journal of Medical Research 12, 23-26

Kuys SS, Brauer SG, Ada L, Russell TG (2008). Increasing intensity during treadmill walking does not adversely affect walking pattern or quality in newly ambulating stroke patients: an experimental study. Australian Journal of Physiotherapy 54, 49-54

Niemann DC (2011). Exercise testing and prascription a health-related approach. 7th ed. New York, McGraw Hill

Norheim F, Langleite TM, Hjorth M, Holen T, Kielland A, Stadheim HK, Gulseth HL, Birkeland KI, Jensen J, Drevon CA (2013). The effects of acute and chronic exercise on PGC-1 $\alpha$, irisin and browning of subcutaneous adipose tissue in humans. FEBS journal 281, 739-49

Panati K, Suneetha Y, Narala VR (2016). Irisin/FNDC5. An updated review in European review for medical and pharmacological sciences journal 20, 689-97

Perakakis N, Triantafyllou GA, Fernandez-Real JM, Huh JY, Park KH, Seufert J, Mantzoros CS (2017). Physiology and role of irisin in glucose homeostasis. Nature Reviews Endocrinology Journal, 1-14

Pescatello LS, Arena R, Riebe D, Thompson PD (eds) (2014). Health-related physical fitness testing and intepratation. ACSM's Guideline for Exercise Testing and Prascription. 9th ed. Philadelphia, Lippincott Williams \& Wilkins, p 73-75, 150-190

Plowman SA, Smith DL (2014). Cardiorespiratory training principes and adaptations. exercise physiology for health, fitness and performance. 4th ed. Philadelphia, Lippincott Williams \& Wilkins, p 392419

Polen ZK, Joshi S (2014). Comparison of treadmill versus cycle ergometer traning on functionsl exercise capacity in normal individuals. IJCRR 6, 61-65

Porszasz J, Casaburi R, Somfay A, Woodhouse LJ, Whiff BJ (2003). A treadmill ramp protocol using simultaneous changes in speed and grade. Medicine 
and Science in Sports and Exercise. doi: 10.1249/ 01.MSS.0000084593.56786.DA

Pratanu S (2008). Buku pedoman kursus elektrokardiografi. Surabaya, Airlangga University Prass, p 61-68

Sanchez-Delgado G, Martinez-Tellez B, Olza J, Aguilera CM, Gil A, Ruiz JR (2015). Role of exercise in the activation of brown adipose tissue. Annuals of Nutrition and Metabolism Journal 67, 21-32

So B, Kim HJ, Kim J, Song W (2014). Exercisedinduced myokines in health and metabolic disease. Review article in Integrative medicine research journal, 173-9

Tang H, Yu R, Liu S, Huwatibieke B, Li Z, Zhang W (2016). Irisin inhibits hepatic cholesterol synthesis via AMPK-SREBP2 signaling. EbioMedicine 6, 139-48

Tsuchiya Y, Ando D, Goto K, Kiuchi M, Yamakita M, Koyama K (2014). High-intensity exercise cause greater irisin response compared with low-intensity exercise under similar energy consumption. Tohoku J. Exp. Med 233, 135-40

World Health Organization (WHO) (2000). Obesity: praventing and managing the global epidemic. Technical Report Series Number 894. Geneva, WHO Publication Data, $\mathrm{p} 9$

Zhang J, Valverde P, Zhu X, Murray D, Wu Y, Yu L, Jiang H, Dard MM, Huang J, Xu Z, Tu Q, Chen J (2017). Exercised-induced irisin in bone and systemic irisin administration reveal new regulatory mechanism of bone metabolism. Bone Research Journal 5, 1-14

Zhang W, Chang L, Zhang C, Zhang R, Li Z, Chai B, li J, Chen E, Mulholland M (2015). Irisin: a myokine with locomotor activity. Neurosci Lett, 1-10

Zhao J, Su Z, Qu C, and Dong Y (2017). Effects of 12 weeks resistance training on serum irisin in older male adults. Frontiers in Physiology, 1-4 